
\title{
ДОСВІД ПРОВЕДЕННЯ КЛІНІЧНОЇ ПРАКТИКИ ДЛЯ ФІЗИЧНИХ ТЕРАПЕВТІВ НА БАЗІ ГЕРІАТРИЧНОГО ПАНСІОНАТУ
}

\author{
I. R. Mysula, T. H. Bakaliuk, H. O. Stelmakh \\ I. Horbachevsky Ternopil National Medical University \\ EXPERIENCE OF CLINICAL PRACTICE FOR PHYSICAL THERAPISTS \\ ON THE BASIS OF GERIATRIC BOARDING HOUSE
}

\begin{abstract}
Анотація. У статті здійснено аналіз ролі клінічної практики для бакалаврів та магістрів зі спеціальності «Фізична терапія. Ерготерапія» на базі геріатричного пансіонату у професійному становленні майбутніх фахівців. Показано, що важливу роль у підготовці фізичного терапевта відіграє клінічна практика, мета якої полягає у перевірці й закріпленні знань, отриманих студентами при вивченні основних клінічних та інших дисциплін, подальшому вдосконаленні практичних навичок, набутих упродовж навчального року, ознайомленні з організацією та умовами роботи фізичного терапевта в медичних закладах.

Під час практики студенти навчаються проводити оцінку функціонального стану серцево-судинної і дихальної систем у хворих похилого віку, що є дуже важливим фактором перед початком курсу реабілітації. Це дає можливість проведення раціонального відновного лікування з адекватним дозуванням фізичних навантажень кожному хворому під час перебування в геріатричному пансіонаті, а також моніторингу ефективності проведених процедур та підбору для кожного пацієнта індивідуального комплексу вправ для подальших занять, оскільки люди похилого віку потребують у програмах реабілітації вправ, що відповідають віковим змінам. Практична орієнтованість викладання клінічної практики для бакалаврів та магістрів зі спеціальності «Фізична терапія. Ерготерапія» на базі геріатричного пансіонату розширює світогляд майбутнього фізичного терапевта і дає можливість індивідуально підібрати реабілітаційне втручання та провести його контроль. Якісна організація клінічної практики для фізичних терапевтів дає можливість закріпити практичні навички у реальних професійних умовах. Формування клінічного мислення, відпрацювання практичних навичок, засвоєння культури спілкування з пацієнтами є основними напрямками навчання 3 клінічної практики для бакалаврів та магістрів зі спеціальності «Фізична терапія. Ерготерапія».
\end{abstract}

Ключові слова: фізичний терапевт; клінічна практика; реабілітація; люди похилого віку.

Abstract. The article analyzes the role of clinical practice for bachelors and masters in the specialty "Physical Therapy. Occupational therapy" on the basis of geriatric boarding house in the professional development of future specialists. It is shown that an important role in the training of physical therapists is played by clinical practice, the purpose of which is to test and consolidate the knowledge gained by students in the study of basic clinical and other disciplines, further improvement of practical skills acquired during the school year, acquaintance with the organization and working conditions in medical institutions.

During the clinical practice, students learn to assess the functional state of the cardiovascular and respiratory systems in elderly patients, which is a very important factor before the start of rehabilitation. This makes it possible to carry out rational rehabilitation treatment with adequate dosage of physical activity for each patient during the stay in the geriatric boarding house, as well as to monitor the effectiveness of procedures and selection of individual exercises for each patient for further training, as elderly people need programs rehabilitation of exercises that correspond to age changes. Practical orientation of teaching clinical practice for bachelors and masters in the specialty "Physical Therapy. Occupational therapy” on the basis of geriatric boarding house expands the worldview of the future physical therapist and gives the chance to pick up rehabilitation intervention individually and to carry out its control. Qualitative organization of clinical practice for physical therapists provides an opportunity to consolidate practical skills in real professional conditions. Formation of clinical thinking, practice of practical skills, mastering the culture of communication with patients are the main areas of training in clinical practice for bachelors and masters in the specialty "Physical Therapy. Occupational therapy".

Key words: physical therapist; clinical practice; rehabilitation; elderly.

Вступ. Перспективною технологією відновлення здоров’я для пацієнтів похилого віку є медична реабілітація, яка є розділом відновної медицини, і

(C) I. Р. Мисула, Т. Г. Бакалюк, Г. О. Стельмах спрямована на вторинну профілактику захворювання, компенсацію порушених функцій та покращення дієздатності. На сьогодні медична реабілітація являє собою диференційовану етапну систему про- 
філактично-лікувальних заходів, що забезпечують цілісність функціонування організму i, як наслідок, - максимальне відновлення здоров'я хворого до оптимального рівня працездатності за допомогою поєднаного, послідовного та узгодженого застосування індивідуального комплексу методів фармакологічної, хірургічної, фізичної і психофізіологічної дії на функціонально або патологічно змінені органи та системи організму [4].

Старіння організму сприяє виникненню та накопиченню хвороб. При обстеженні в осіб похилого та старечого віку діагностують від трьох до п’яти різних захворювань. Сучасна людина похилого віку - унікальний клінічний феномен з точки зору наявності і поєднання у неї різноманітних за характером і перебігом захворювань, які конкурують за своєю прогностичною значимістю та впливають на якість життя [2].

Оскільки адаптаційні можливості старіючого організму знижені, ймовірність розвитку різних захворювань збільшується. У зв'язку з цим, особливо важлива в разі розвитку захворювань у пацієнтів похилого віку роль саногенетичних механізмів, їх стимуляція і підтримка.

Слід зазначити, що старіння є суперечливим процесом, оскільки на тлі регресивних процесів перебудови - атрофії, деградації та ін. розвиваються прогресивні тенденції формування нових компенсаторно-пристосувальних механізмів, спрямованих на підтримання гомеостазу старіючого організму, що, однак, повністю не компенсує наростаючих явищ деградації [2]. Тому ефективність для людей похилого віку мають реабілітаційні методи саногенетичної спрямованості, які підвищують неспецифічну резистентність організму і відновлюють його функціональні резерви [4].

Фізична терапія є невід'ємною частиною системи охорони здоров'я з надання медичних послуг та соціального забезпечення. Фізичні методи терапії застосовуються для розвитку, підтримки та відновлення руху, максимальних функціональних можливостей, а також потреб людини протягом усього ії життя. Особливе значення фізична терапія має в тих випадках, коли нормальний рух і функція під загрозою травми, хвороби, болю, старіння [3].

Мета статті - аналіз проходження клінічної практики в геріатричному пансіонаті для бакалаврів та магістрів із спеціальності «Фізична терапія. Ерготерапія».

Теоретична частина. На сьогодні фахівці з фізичної терапії є провідними спеціалістами з відновлення, корекції та підтримки рухових функцій. Вони володіють системними знаннями у сфері рухової діяльності людини. Клінічна діяльність фізичних терапевтів складається з реабілітаційного обстеження, оцінювання, визначення реабілітаційного діагнозу, складання прогнозу та здійснення реабілітаційного втручання. Обстеження обов'язково передує будьякому втручанню. Відмінною особливістю фізичної терапії $є$ професійне клінічне мислення, яке грунтується на фізіотерапевтичній діагностиці та оцінці з урахуванням нозології пацієнта. Також метою діагностики $є$ визначення прогнозу, головних цілей, засобів і методів фізичної терапії для найбільш відповідних стратегій реабілітації.

Фізичні терапевти планують і курують програмами фізичної реабілітації, що включають навчання, консультування та реабілітацію в різноманітних умовах, відповідаючи потребам як однієї людини, так і групи людей у районі їхнього проживання. Пацієнт може отримати даний вид реабілітаційних інтервенцій у стаціонарах, будинках для людей похилого віку, будинках для інвалідів, школах, на виробництві, у спортивних та рекреаційних центрах, удома [3].

Здобуття студентами теоретичних знань відбувається під час лекцій, семінарських занять, консультацій, самостійної роботи з літературою, участі в наукових гуртках, конференціях, семінарах, диспутах тощо. Практична підготовка реалізується через практичні заняття, самостійне виконання практичних завдань, індивідуальну роботу та клінічну практику.

Особливо важливу роль у підготовці фізичного терапевта відіграє клінічна практика, мета якої полягає у перевірці й закріпленні знань, отриманих студентами при вивченні основних клінічних та інших дисциплін, подальшому вдосконаленні практичних навичок, набутих упродовж навчального року, ознайомленні з організацією та умовами роботи фізичного терапевта в медичних закладах.

Клінічна практика дає можливість студентам ознайомитись $з$ основами етики й медичної деонтології, а також набути й закріпити навички, професійно необхідні фізичному терапевту.

На кафедрі медичної реабілітації Тернопільського національного медичного університету імені I. Я. Горбачевського клінічна практика для бакалаврів II, IV курсів та магістрів I, II курсів зі спеціальності «Фізична терапія. Ерготерапія» періодично проводиться на базі геріатричного пансіонату в Тернопільському районі.

Пацієнтом похилого віку, окрім лікуючого лікаря, займаються ще двоє студентів у якості фізичного 
терапевта та ерготерапевта. При налагодженні взаємодії між фахівцями за типом мультидисциплінарної моделі командного підходу під час проведення реабілітаційних заходів розробляється індивідуальна програма реабілітації, в основу якої покладений принцип багатофакторного впливу на організм хворого та використовуються взаємодоповнюючі засоби і методи медикаментозного та немедикаментозного впливу, в тому числі прораховуються ризики формування несприятливих наслідків захворювання.

При складанні індивідуальних програм реабілітації для пацієнтів похилого віку враховується адаптаційний потенціал організму, стан компенсації, функціональні обмеження з боку опорно-рухового апарату, характер супутньої патології. У програмі реабілітації використовуються різні форми немедикаментозних впливів: дієтотерапія, кінезіотерапія, фізіотерапія, механотерапія та ін. Завданнями психологічного супроводу медичної реабілітації є вироблення у пацієнта мотивації на участь у реабілітаційному процесі.

Також під час практики студенти навчаються проводити оцінку функціонального стану серцевосудинної і дихальної систем у хворих похилого віку, що є дуже важливим фактором перед початком курсу реабілітації. Це дає можливість проведення раціонального відновного лікування з адекватним дозуванням фізичних навантажень кожному хворому під час перебування в геріатричному пансіонаті, а також моніторингу ефективності проведених процедур та підбору для кожного пацієнта індивідуального комплексу вправ для подальших занять, оскільки люди похилого віку потребують у програмах реабілітації вправ, що відповідають віковим змінам.

Призначення і контроль проведення заходів реабілітації здійснює лікуючий лікар. Щоденний контроль адекватності фізичних навантажень проводять студенти, що дозволяє лікарю прогнозувати очікувані результати медичної реабілітації, які відображають зміни в стані здоров'я пацієнта похилого віку після проведеного курсу реабілітаційних заходів, й оцінювати за допомогою комплексних критеріїв на рівні клінічних проявів, оздоровчого ефекту та медико-соціальних показників.

Розклад для дисциплін з клінічної практики складений таким чином, що групи студентів змінюються почергово і спостереження за пацієнтом відбувається протягом 6 місяців, що дає змогу проводити реабілітаційні заходи як у довготривалому періоді реабілітації. Також студенти вивчають попередні ефекти проведених реабілітаційних втручань на фізичну здатність, функціональне та психологічне здоров’я і якість життя людей похилого віку, які проживають у геріатричному пансіонаті.

Додатково у студентів є змога практично застосовувати «Міжнародну класифікацію функціонування, обмежень життєдіяльності та здоров’я» (МКФ) під час реабілітаційного процесу $[1,7]$. По-перше, застосування МКФ допомагає описувати порушення та обмеження, які виникають у людини внаслідок захворювання, травми чи патологічного стану. По-друге, застосування МКФ допомагає уніфікувати встановлення реабілітаційного діагнозу, визначити мету та завдання фізичної терапії, оцінити ефективність реабілітації. По-третє, встановлення реабілітаційного діагнозу кожним членом мультидисциплінарної команди забезпечує спільну мову для функціонування людини, що полегшує координацію реабілітаційних втручань.

Отже, під час клінічної практики студенти орієнтуються не тільки на клінічний діагноз, але і на МКФ в якості основи для постановки реабілітаційного діагнозу [5, 6].

Викладачі кафедри медичної реабілітації здійснюють загальне керівництво та контроль за роботою студентів, проводять консультативнороз'яснювальну роботу серед медичного персоналу та студентів.

Під час проходження виробничої практики студенти одночасно можуть і відпрацьовувати уміння та навички, і спостерігати за роботою досвідчених фахівців, і адаптуватись до умов конкретного робочого місця. Крім того, виробнича практика дає студентам можливість не лише отримати оцінку відповідно до рівня засвоєння знань й оволодіння уміннями та навичками, а й отримати зворотний зв'язок від діючих професіоналів. Виробнича практика, як перший досвід наближення студента до самостійної професійної діяльності, є надзвичайно важливим чинником становлення майбутнього професіонала.

Висновки та перспективи подальших досліджень. Практична орієнтованість викладання клінічної практики для бакалаврів та магістрів із спеціальності «Фізична терапія. Ерготерапія» на базі геріатричного пансіонату розширює світогляд майбутнього фізичного терапевта і дає можливість індивідуально підібрати реабілітаційне втручання та провести його контроль.

Якісна організація клінічної практики для фізичних терапевтів дає можливість закріпити практичні навички у реальних професійних умовах. 
Формування клінічного мислення, відпрацювання практичних навичок, засвоєння культури спілкування з пацієнтами є основними напрямками навчання 3 клінічної практики для бакалаврів та магістрів зі спеціальності «Фізична терапія. Ерготерапія».

\section{Список літератури}

1. Использование международной классификации функционирования (МКФ) в амбулаторной и стационарной медицинской реабилитации: инструкция для специалистов / Е. В. Мельникова, Т. В. Буйлова, Р. А. Бодрова [и др.] // Вестник восстановительной медицины. - 2017. - № 6 (82). - С. 2-20.

2. Казимирко В. К. Инволюционный остеоартроз и остеопороз / В. К. Казимирко, В. Н. Коваленко, В. В. Флегонтова. - Донецк : Издатель Заславский А. Ю., 2011. 722 c.

3. Кобелєв С. Ю. Сфера діяльності фізичного терапевта/фахівця фізичної реабілітації / С. Ю. Кобелєв // Український вісник медико-соціальної експертизи. - 2015. - № 1. - С. 25-30.

4. Медична реабілітація: сучасні стандарти, тести, шкали та критерії ефективності. Низькоінтенсивна резонансна фізіотерапія і іï застосування в реабіліта-

\section{References}

1. Melnykova, E.V., Buylova, T.V., \& Bodrova, R.A. (2017). Vykorystannia Mizhnarodnoi klasyfikatsii funktsionuvannia (MKF) v ambulatornii ta statsionarnii medychnii reabilitatsii: posibnyk dlia fakhivtsiv [Use of the International Classification of Functioning (ICF) in outpatient and inpatient medical rehabilitation: A manual for specialists]. Reporter vidnovnoi medytsyny - The Reporter of Restorative Medicine, 6 (82), 2-20 [in Russian].

2. Kazimirko, V.K., Kovalenko, V.N., \& Flegontova, V.V. (2011). Involyutsionnyy osteoartroz i osteoporoz [Involutional osteoarthritis and osteoporosis]. Donetsk: Izdatel Zaslavskiy A. Yu. [in Ukrainian].

3. Kobeliev, S.Iu. (2015). Sfera diialnosti fizychnoho terapevta/ fakhivtsia fizychnoi reabilitatsii [Scope of activity of a physical therapist/physical rehabilitation specialist]. Ukrainskyi visnyk medyko-sotsialnoi ekspertyzy -Ukrainian Bulletin of Medical and Social Expertise, 1, 25-30 [in Ukrainian].

4. Lyseniuk, V.P., Samosiuk, I.Z., Fisenko, L.I., \& Zozulia, I.S. (2007). Medychna reabilitatsiia: suchasni standarty, testy, shkaly ta kryterii efektyvnosti. Nyzkointensyvna rezonansna fizioterapiia i yii zastosuvannia $v$ reabilitatsii-
Перспективи подальших досліджень полягають у розширенні можливостей для практики бакалаврів та магістрів із спеціальності «Фізична терапія. Ерготерапія» залежно від обраного напрямку реабілітації, шляхом збільшення кількості клінічних баз та залучення студентів до наукових досліджень під час проходження практики.

ційній медицині : навч.-метод. посіб. / за ред. В. П. Лисенюка, І. З. Самосюка, Л. І. Фісенко, І. С. Зозулі. - К. : ВПЦ «Київський університет», 2007. - 264 с.

5. Романишин Н. Я. Основы построения реабилитационного диагноза в клинической практике физическим реабилитологом / Н. Я. Романишин // Педагогіка, психологія та медико-біологічні проблеми фізичного виховання і спорту. - 2012. - № 1. - С. 94-96.

6. Methodology of "Physical and rehabilitation medicine practice, evidence based position papers: theEuropean position" produced by the UEMS-PRM section / S. Negrini, C. Kiekens, M. Zampolini [et al.] // Eur. J. Phys. Rehabil. Med. - 2016. - Vol. 52, No. 1. - P. 134-141.

7. White book on physical and rehabilitation medicine in Europe // European Journal of Physical and Rehabilitation Medicine. - 2018. - Vol. 54 (2). - P. 125-321.

nii medytsyni: navchalno-metodychnyi posibnyk [Medical rehabilitation: modern standards, tests, scales and performance criteria. Low-intensity resonance physiotherapy and its application in rehabilitation medicine: a textbook]. Kyiv: Kyiv University [in Ukrainian].

5. Romanyshyn, N.Ya. ( 2012). Osnovy postroeniya reabilitatsyonnogo diagnoza v klinicheskoy praktike fizicheskym reabilitologom [Fundamentals of the construction of a rehabilitation diagnosis in clinical practice by a physical rehab]. Pedahohika, psykholohiia ta medyko-biolohichni problemy fizychnoho vykhovannia i sportu - Pedagogics, Psychology and Medical and Biological Problems of Physical Education and Sports, 1, 94-96 [in Russian].

6. Negrini, S., Kiekens, C., \& Zampolini, M. (2016). Methodology of "Physical and rehabilitation medicine practice, evidence based position papers: the European position" produced by the UEMS-PRM section. Eur. J. Phys. Rehabil. Med, 52 ( 1), 134-141.

7. (2018). White book on physical and rehabilitation medicine in Europe. European Journal of Physical and Rehabilitation Medicine, 54 (2), 125-321. 